\title{
3-Dimensional LADAR Optical Detector Development in Geiger Mode Operation
}

\author{
Soon-Gyu Choi ${ }^{1 \dagger}$, Jung-Hwan Shin ${ }^{1}$, Sang-Gu Kang ${ }^{2}$, Jung-Ho Hong ${ }^{2}$, Yong-Joon Kwon ${ }^{3}$, \\ Eung-Cheol $\mathrm{Kang}^{3}$, and Chang-Jae Lee ${ }^{3}$ \\ ${ }^{1}$ Yong In R\&D Center, Samsung Thales, 304, Chang-li, Namsa-myeon, Cheoin-gu, Yongin 449-885, Korea \\ ${ }^{2}$ Research Institute, I3system, 60-3 Jang-dong, Yusong-gu, Daejeon 305-343, Korea \\ ${ }^{3}$ Agency for Defense Development(ADD), 111 Sunam-dong, Yusong-gu, Daejeon 305-152, Korea
}

(Received April 19, 2013; Revised manuscript June 19, 2013; Accepted June 25, 2013)

\begin{abstract}
In this paper, we report the design, fabrication and characterization of the 3-Dimensional optical receiver for a Laser Detection And Ranging (LADAR) system. The optical receiver is composed of three parts; $16 \times 16$ Geiger Mode InGaAs Avalanche Photodiode (APD) array device operated at $1560 \mathrm{~nm}$ wavelength, Read Out Integrated Circuit (ROIC) measuring the Time-OfFlight (TOF) of the return signal reflected from target objects, a package and cooler maintaining the proper operational condition of the detector and control electronics. We can confirm that the LADAR system can detect the signal from a target up to 1.2 $\mathrm{km}$ away, and it showed low Dark Count Rate (DCR) of less than $140 \mathrm{kHz}$, and higher than 28\%-Photon Detection Efficiency (PDE). This is considered to be the best performance of the $16 \times 16$ FPA APD optical receiver for a LADAR system.
\end{abstract}

Keywords: InGaAs APD, LADAR, Avalanche photodiode, Light detection and ranging

OCIS codes: (040.1345) Avalanche photodiodes (APDs); (040.5160) Photodetectors; (250.1345) Avalanche photodiodes (APDs); (280.3400) Laser range finder; (280.3640) Lidar

\section{Geiger Mode로 동작하는 3차원 LADAR 광수신기 개발 최순규 $^{1 \dagger} \cdot$ 신정환 ${ }^{1} \cdot$ 강상구 $^{2} \cdot$ 홍정호 $^{2} \cdot$ 권용준 $^{3} \cdot$ 강응철 $^{3} \cdot$ 이창재 $^{3}$ \\ ${ }^{1}$ 삼성탈레스(주), ISR·PGM 연구소 \\ (ㅇ) 449-885 경기도 용인시 처인구 남사면 창리 304번지}

${ }^{2}$ 아이쓰리시스템(주)

(ㅇ) 305-343 대전광역시 유성구 장동 60-3번지

${ }^{3}$ 국방과학연구소

(ㅇ) 305-152 대전광역시 유성구 수남동 111번지

(2013년 4월 19일 받음, 2013년 6월 19일 수정본 받음, 2013년 6월 25일 게재 확정)

본 논문에서는 3차원 영상 획득을 위한 LADAR(LAser Detection And Ranging)용 광수신기 모듈을 설계-제작하고 측정한 결과 를 보고한다. 광수신기 모듈은 $1 \mathrm{~km}$ 이상의 거리에서도 신호를 측정할 수 있도록 디지털모드(Geiger Mode)에서 동작하는 InGaAs $\mathrm{APD}$ (Avalanche Photodiode)로 설계하였으며, 16×16 FPA(Focal Plane Array)로 설계-제작하였다. 디지털모드(Geiger Mode)는 항 복전압 이상의 영역에서 동작하여 작은 광에 대해 반응 할 수 있게 큰 증폭률을 가지게 된다. 1ns의 FWHM(Full Width at Half Maximum)을 갖는 펄스를 수광할 수 있고, 배열 크기는 $16 \times 16$, Geiger Mode 동작 등의 특성을 만족하도록 광수신기를 구성하기 위해 ROIC(Read Out Integrated Circuit)를 자체적으로 설계-제작하였다. 제작된 광수신기 모듈은 원거리 표적정보 획득이 가능하 며, PDE(Photon Detection Efficiency)는 28\%, DCR(Dark Count Rate)은 $140 \mathrm{kHz}$ 이하의 특성을 보였으며, LADAR 시스템에서 3 차원 영상을 획득하였다. 이는 $16 \times 16 \mathrm{FPA} \mathrm{APD}$ 를 이용한 광수신기에서 가장 우수한 특성을 나타낸 것이다.

Keywords: 인듐 갈륨 비화물 애벌런치 광포토다이오드, 레이저 레이더, 애벌런치 광포토다이오드, 라이다

OCIS codes: (040.1345) Avalanche photodiodes (APDs); (040.5160) Photodetectors; (250.1345) Avalanche photodiodes (APDs); (280.3400) Laser range finder; (280.3640) Lidar

\footnotetext{
${ }^{\dagger}$ E-mail: soongyu.choi@samsung.com
}

Color versions of one or more of the figures in this paper are available online. 


\section{I. 서 론}

III-V족 화합물 반도체 분야에서 $\mathrm{InGaAs} / \mathrm{InP}$ 계를 이용한 $\mathrm{APD}$ 는 1980년대부터 수십 $\mathrm{GHz}$ 대역의 광 통신 신호를 전 달하는 목적으로 연구되었다. 최근에는 이를 이용한 능동형 이미지 센서의 연구가 진행 중이다. ${ }^{[1]} \mathrm{InGaAs}$ 반도체는 에너 지 밴드 갭이 $0.75 \mathrm{eV}$ 로 1.1 1.6 um 대역의 NIR(Near Infrared) 을 검출할 수 있는 능력을 갖고 있다. 특히 $1.55 \mathrm{um}$ 대역의 $\mathrm{NIR}$ 은 대기 환경에서 흡수가 작으면서도 눈에 해롭지 않은 특성을 가지고 있어 앞으로 군사용, 차량용, 로봇 분야 등 응 용 분야가 점차 넓어지고 있다. 광수신기에는 원거리의 3 차 원 영상 획득을 위해 주로 $\mathrm{APD}$ 가 활용되고 있다. $\mathrm{APD}$ 는 선 형모드(Linear mode)에서 동작하는 $\mathrm{APD}$ 와 디지털모드(Geigermode)에서 동작하는 $\mathrm{APD}$ 로 구분이 가능하며, 디지털모드 (Geiger Mode) APD는 항복 전압 이상에서 구동하여 신호의 크기를 10,000 배 이상 증폭시키므로 전치증폭기가 필요 없 는 대신 입력광의 세기와 무관하게 출력 광전류가 일정하고, 선형모드(Linear mode) APD는 항복전압 이하의 영역에서 동작시킴으로써 증폭이 10 100 정도에서 사용하게 되며, 전 치증폭기가 필요하게 되고 출력신호의 크기는 입력광신호의 세기에 따라 비례하다.

본 연구의 목표로는 $\mathrm{InGaAs} / \mathrm{InP}$ 계 $\mathrm{APD}$ 소자를 제작하여 단일 광자를 검출할 수 있는 초고감도 센서 $16 \times 16 \mathrm{FPA}$ 를 제 작하고 이를 이용해 3 차원 영상을 얻는 LADAR 광수신기를 구현하고자 한다. LADAR는 빛이 이동하는 거리에 따른 시 간차를 검출하는 방식(TOF)으로 3차원 영상 정보를 획득하 며, 원거리의 표적 정보를 획득하기 위해서는 아주 약한 신 호를 감지하면서도 신호가 크고, 잡음의 크기가 작은 특성이 요구된다. 이를 위해, 빛의 기본 단위인 단일 광자 수준까지 도 검출할 수 있는 디지털모드(Geiger Mode) APD 광수신기 를 설계-제작하였다. 레이저 광의 $\mathrm{TOF}^{[2]}$ 방식을 이용한 3 차 원 영상획득기술은 펄스광원을 조사하고 반사되는 빛을 광 수신기로 검출하여 펄스의 왕복 시간과 세기를 측정함으로 써 물체와의 거리를 측정하는 방식으로 광원과 광수신기에 따라 여러 방면에 응용되고 있다.

본 연구에서는 3 차원 영상을 얻기 위해 회전 거울을 이용 하여 광원을 2 차원으로 주사하는 방식으로 동작하는 디지털 모드(Geiger Mode)의 $16 \times 16 \mathrm{FPA} \mathrm{APD}$ 광수신기를 성공적으 로 제작한 결과에 대해 보고한다.

\section{II. 광수신기 설계}

본 연구에서의 LADAR 광수신기는 Eye-Safe 영역인 $1.56 \mathrm{um}$ 파장에서 동작하는 $16 \times 16$ 디지털모드(Geiger Mode) $\mathrm{InGaAs}$ $\mathrm{APD}$ 배열소자, 목표물에 반사되어서 돌아오는 레이저의 $\mathrm{TOF}$ 측정을 위한 $\mathrm{ROIC}$, 검출기의 동작조건 설정을 위한 패 키지 및 냉각기로 구성된다.

광수신기는 수광 직경 $25 \mathrm{um}$ 의 $16 \times 16 \mathrm{FPA}$ 를 갖는 $\mathrm{APD}$ 칩과 목표물에 되돌아오는 레이저의 $\mathrm{TOF}$ 측정을 위한 $\mathrm{ROIC}$
가 핵심 부품이고, 그 외 바이어스 공급회로, $\mathrm{APD}$ 보호회로, 잡음차단 필터, 냉각기로 구성된다.

최근 $\mathrm{LADAR}$ 분야에 대한 연구는 구동 방식에 따라 디지 털모드(Geiger-mode)와 선형모드(Linear-mode)로 구분된다. 디지털모드(Geiger-mode)는 현재까지 기술 수준으로 단일 광 자를 검출 할 수 있는 유일한 방법이며, 선형모드(Linearmode)의 경우 신호 분석이 가능하다는 장점이 있으나 고속 동작을 위한 증폭기 설계의 경우 기존의 $\mathrm{Si} \mathrm{CMOS공정의} \mathrm{한}$ 계로 인해 제작 상 어려움이 존재하여 $\mathrm{SiGe등을} \mathrm{이용한}$ $\mathrm{ROIC}$ 설계에 대한 연구가 진행 중이고, ${ }^{[4]}$ 과잉 잡음 지수 (Excess noise factor)를 줄이기 위해 증폭층에 InAlAs, MCT 와 같은 물질을 이용한 연구가 진행 중이다.

본 연구에서는 검출 민감도가 매우 높고, 신호처리 과정이 단순하여 단일 광자까지 검출 가능한 디지털모드(Geigermode) APD FPA 검출기를 사용하여 3차원 영상 LADAR의 개발을 목표로 하였다. 디지털모드(Geiger-mode)는 일반적으 로 사용되고 있는 광통신 소자의 선형모드(Linear-mode)와 달리 항복전압 이상에서 동작하는 것이 특징으로 각각의 소 자들이 균일한 항복전압 값을 가져야 함은 물론 동작 시 전 자사태(Avalanche)가 일어나기 전에 암 전류(Dark Current)값 을 낮게 형성하도록 하여 전자사태(Avalanche)가 발생 했을 때 증폭에 의한 이득이 크도록 하여야 단일 광자를 검출 할 수 있다.(그림 1 참조) 그러므로 소자 설계 시 고전압이 인가 되므로 균일한 항복전압과 잡음에 의한 전자사태(Avalanche) 를 억제하도록 설계 되어야 한다.

디지털모드(Geiger-mode)로 구동하는 소자의 경우 크게 두 가지 형태로 소자를 제작하는 것이 가능하다. 첫 번째는 MIT Lincoln lab에서 제작하는 방법으로 메사(Mesa)구조이다. ${ }^{[3]}$ 메 사(Mesa) 구조는 빛이 입사되는 면적을 제외한 부분을 식각 을 통해 제거한 구조로 평면 구조와 달리 각 에피(Epi)층의 형성이 평면구조와 비교해 역의(Inverse)형태로 제작된 것이 특징이라 할 수 있다. 반면 플래너(Planar)구조는 일반적인 $\mathrm{APD}$ 를 제작하는 구조로 $\mathrm{P}+$ 영역을 확산을 통해 형성하는 방 법으로, 직접 $\mathrm{P}+$ 를 형성함으로써 도핑 농도와 두께를 쉽게 조절하는 것이 가능하고 다양한 접합 형태를 이용해 소자 특

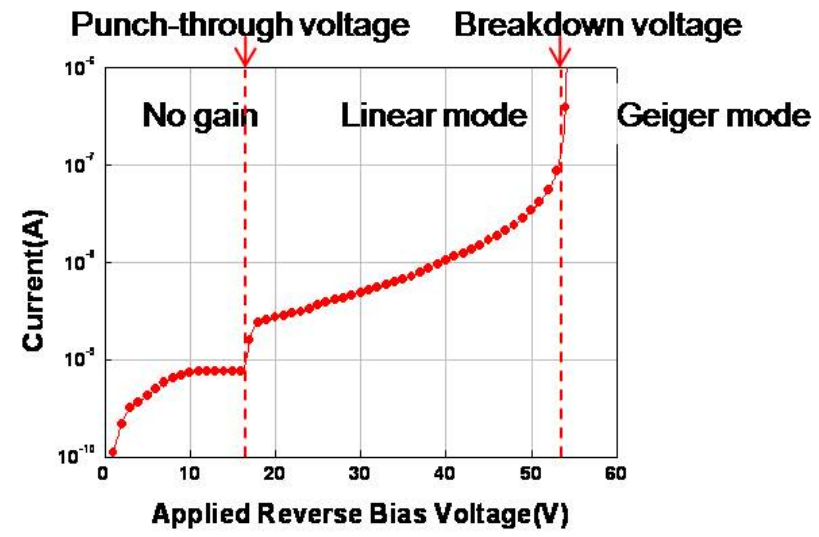

FIG. 1. Geiger mode and linear mode of APD. 
TABLE 1. Comparisons of Planar-structure and Mesa-structure

\begin{tabular}{|c|c|c|}
\hline & Planar & Mesa \\
\hline Structure & $p+p$ guard & $\begin{array}{l}\text { Contact } y \\
\text { Oxide } \\
\text { Contáct }\end{array}$ \\
\hline Advantage & $\begin{array}{l}\text { - Lower surface leakage } \\
\text { current } \\
\text { - Adjustable P+ cambium } \\
\text { - Lower metal contact } \\
\text { resistance } \\
\text { - Low wafer, Edge price }\end{array}$ & $\begin{array}{l}\text { - Accurate active area } \\
\text { - No electric field } \\
\text { concentration at the edge } \\
\text { - Less cross talk }\end{array}$ \\
\hline Disadvantage & $\begin{array}{l}\text { - Non-uniform } \\
\text { Break-down voltage } \\
\text { - More cross talk } \\
\text { - Large electrostatic capacity }\end{array}$ & $\begin{array}{l}\text { - High surface leakage } \\
\text { current } \\
\text { - High metal contact } \\
\text { resistance } \\
\text { - Difficult and expensive } \\
\text { production }\end{array}$ \\
\hline
\end{tabular}

성을 극대화 할 수 있다. 또한 웨이퍼의 수급도 용이하여 쉽 게 제작이 가능하여, 본 연구에서는 3 차원 영상 LADAR 광 수신기 소자 제작을 위해 플래너(Planar)구조를 채택하였다.

본 연구에서는 SACM 구조 웨이퍼를 LADAR 광수신기의 $\mathrm{APD}$ 제작에 사용하였다. 이와 같은 웨이퍼는 총 8 개의 층으 로 구성되어 있으며 암 전류(Dark Current)생성을 최소화하 기 위해 Charge sheet 층을 제외하고는 Undoped-type으로 제 작되었고, 흡수층에 다시 Field stop 층이 존재하는 것이 특 징으로 $\mathrm{Zn}$ 확산을 통해 8 번째 층에 $\mathrm{P}+$ 영역을 형성하였다.

그림 2(a)는 SIMS를 이용하여 각 에피(Epi)층들의 두께를 분석한 것으로 Charge sheet layer의 도펀트는 $\mathrm{Si}$ 로서 설계 두께는 0.4 um로 SIMS 결과와 일치하고 흡수층인 InGaAs의 두께 또한 $2.2 \mathrm{um}$ 로 웨이퍼 설계와 일치하였다.

웨이퍼 구조를 잘못 설계할 경우 소자 제작이 불가능할 수 있으므로 사전에 검증하고자 소자의 동작 전압과 전계 분포 를 K.S.Hyun에 의한 식으로 추론하였다. ${ }^{[5]}$

- 항복전압은 흡수층의 공핍화가 두께 edge에 도달할 때 로 정의

- $\mathrm{P}+/ \mathrm{N}+\mathrm{InP}$ 의 경계면은 가파르다고 가정

- 증폭층 두께에 따른 항복전압, 침식 전압(Punch-through voltage), 전계 분포를 계산

그림 2(b)는 실제 항복 전압 인가 시 각 에피(Epi)층에 인 가되는 전계분포를 도시한 것으로 Charge sheet층에 의해 Absorber층으로 전계 인가가 크게 감소되는 것을 확인하였다.

그림 2(c)는 예측된 항복 전압 및 전계분포에 대한 그래프 로서 증폭층 $0.1 \mathrm{um}$ 증가 시 $4.5 \mathrm{~V} / 0.1 \mathrm{um}$ 의 전압 증가 현 상이 예측되고 증폭층의 두께가 증가할수록 증폭층에 인가 되는 전계세기가 약해짐을 알 수 있다. 이는 낮은 암 전류

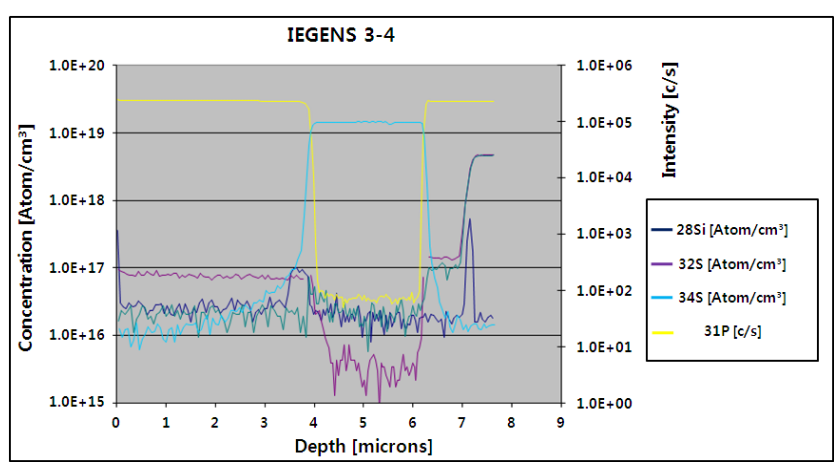

(a)
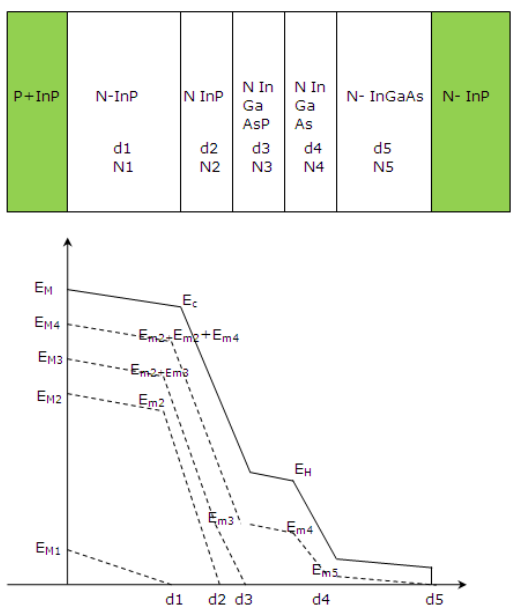

(b)

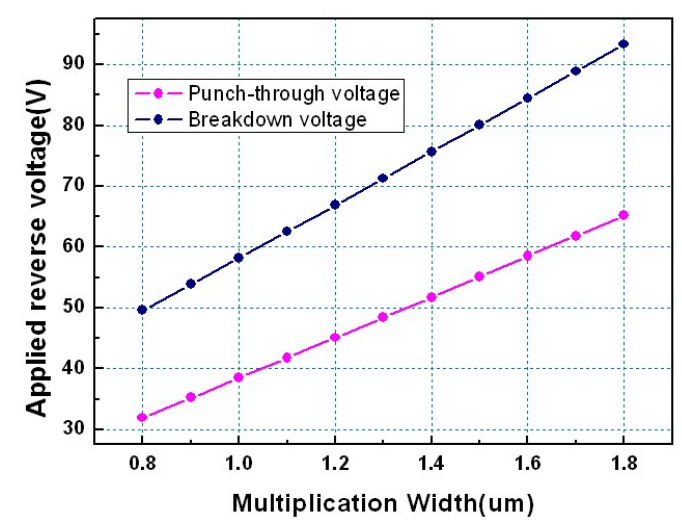

(c)

FIG. 2. (a) Analysis of IEGENS 3-4 SIMS (b) The electric field distribution on the breakdown voltage of the IEGEN 3-4 structure (c) The breakdown voltage and the Punch-through voltage of the calculated IEGENS 3-4.

특성을 갖는 소자를 제작하기 위해서는 증폭층 두께를 크게 하여야 하고, 소자 제작에 있어 증폭층 두께에 상관없이 항 복전압은 항상 침식 전압의 뒤쪽에 존재하므로 소자를 제작 하여 냉각을 하여도 침식 전압에 도달하기 전에 전자사태 (Avalanche)가 발생하여 항복 현상이 일어나는 경우는 없을 것으로 추정할 수 있다. 
단위 소자 및 $16 \times 16$ 배열소자 설계에 있어 주요한 관점은 플래너(Planar)구조의 단점인 불균일한 항복 전압 특성을 개 선하기 위해 P-N접합 형상에 따른 결과 확인이 필요하다는 것이다. 따라서 소자 설계에서는 $\mathrm{Zn}$ 단일 확산의 경우 접합 가장자리에 전계가 집중되어 항복전압 아래에서 항복 현상 이 발생하는 경계 항복(Edge breakdown)을 억제하도록 이중 확산 공정을 실시하였고, 이중 확산을 통한 P-N 접합면에서 의 전계 분포를 더욱 균일해지도록 만들기 위해 접합 가장자 리에 가드링(Guard ring)을 설치하여 균일한 항복 전압을 갖 도록 설계/제작하였다. 그리고 배열소자 제작 시 특성을 유 추하기 위해 그림 3 과 동일한 형상의 소자를 $16 \times 16$ 형태로 배열하여 소자를 설계하였다.

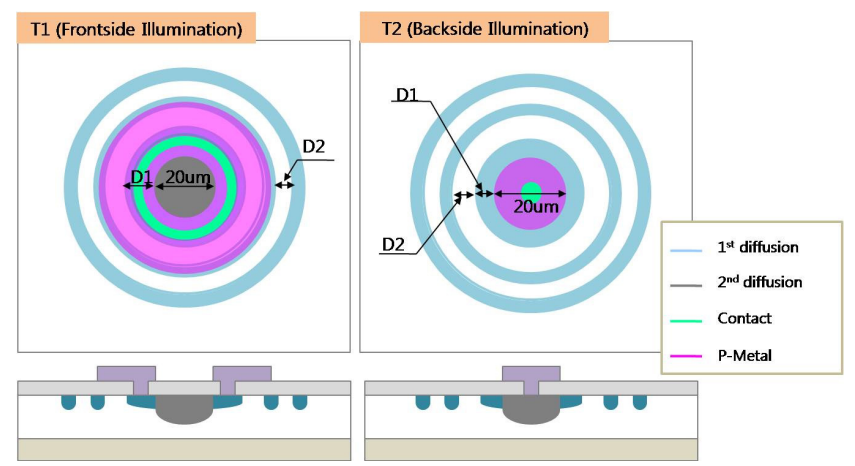

FIG. 3. Structure of InGaAs FPA APD.

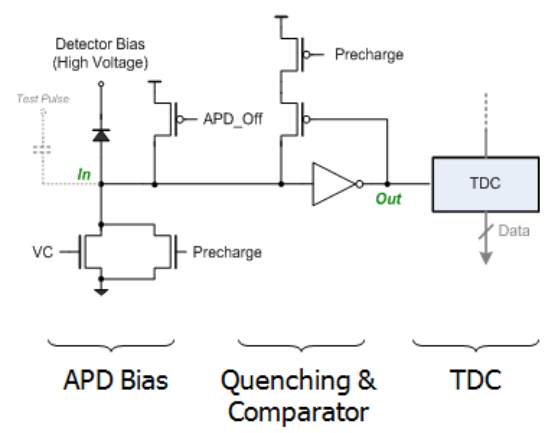

(a)

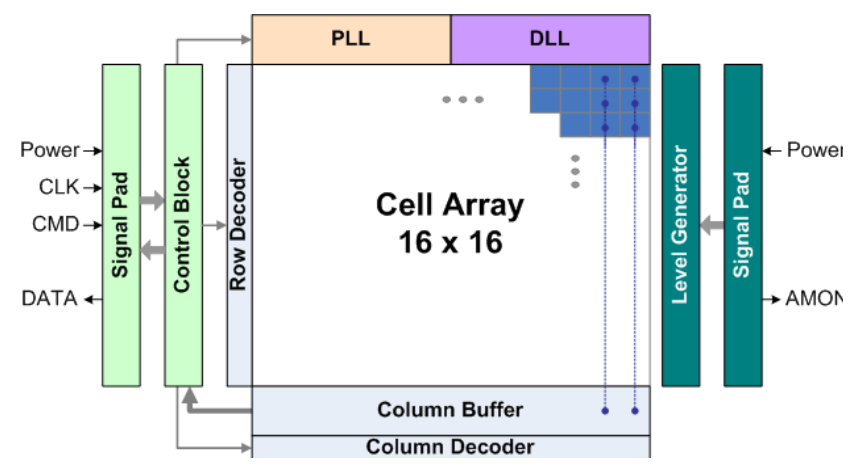

(b)

FIG. 4. (a) Design of ROIC (b) Functional block diagram of ROIC.
- 빛의 입사 형태에 따른 BSI(Back-side illumination)

- 빛의 입사면적을 $25 \mathrm{um}$

- 이중 확산에 따른 접합 거리(d1)

- Main Junction과 Guard ring 의 간격(d2)

$\mathrm{ROIC}$ 는 $\mathrm{InGaAs} \mathrm{APD}$ 배열소자에서 나오는 전류 신호를 전압 신호로 변환하고, 이를 디지털로 변환하여 저장한 다음 각각의 배열 정보를 순차적으로 접근하여 출력하는 역할을 한다.

그림 4(a)는 ROIC의 회로도를 나타낸다. ROIC는 APD 소 자의 디지털모드(Geiger Mode)를 위한 Bias 전압 공급 회로, Quenching 동작 및 비교 동작을 수행하는 Quenching 및 Comparator, 시간정보를 디지털 정보로 변환하기 위한 $\mathrm{TDC}$ (Time to digital converter)로 구성된다. ${ }^{[6]}$

그림 4(b)는 위와 같은 입력회로를 바탕으로 설계한 ROIC 의 블록도를 나타낸다. ROIC는 하나의 화소(Pixel)안에 모두 구현이 되고 이런 회로가 $16 \times 16$ 배열을 형성한다. 회로의 TDC동작을 위해서 고속 Clock 생성을 위한 PLL(Phase Locked Loop)과 DLL(Delay Locked Loop)을 사용하였고, 각 화소(Pixel)별로 생성된 데이터는 컬럼버퍼(Column Buffer) 를 통해서 외부로 출력되는 구조를 가지며, 이러한 동작은 내부 제어 회로부에서 제어되는 형태이다.

\section{III. 제 작}

$\mathrm{InGaAs} \mathrm{APD}$ 소자는 $\mathrm{Zn}$-확산 방법으로 제작하였다. 확산 을 통한 도핑에서 우선적으로 확산 도펀트로서는 $\mathrm{Zn}$ 와 $\mathrm{Cd}$ 으 로 나눌 수 있다. $\mathrm{Zn}$ 와 $\mathrm{Cd}$ 는 도펀트로서 적용이 가능하나 주로 $\mathrm{Zn}$ 를 이용하는 것은 $\mathrm{Cd}$ 의 경우 $\mathrm{Zn}$ 에 비해 확산온도와 시간이 장시간 요구되는 것이 특징으로 가능한 공정 시간을 단축하고 확산 온도를 낮추어 에피(Epi)층의 영향을 최소화 하는 $\mathrm{Zn}$ 를 이용한 확산 방법이 이루어진다. ${ }^{[7]}$

본 연구에서 3 차원 영상 LADAR 광수신기 배열소자 제작 은 S-doped $\left(\mathrm{n}^{+}\right) \mathrm{InP}$ 기판 상에 Substrate층, Absorption층, Field control층, Grading층, Field control층, Multiplication층 및 Junction층이 차례로 성장된 웨이퍼 상에 활성영역을 식 각으로 에칭하고 $\mathrm{Zn}$-확산을 진행하였다.

샘플표면을 외부 환경으로 부터 보호하기 위해 $\mathrm{SiO}_{2}$ 와 폴 리이미드(Polyimide)를 채택하였다. $\mathrm{SiO}_{2}$ 는 확산 방지막을 형 성하는 공정과 동일한 공정으로 $\mathrm{PECVD}$ 를 이용하여 증착 하 였으며, 폴리이미드는 스핀코팅 방식으로 보호막을 형성하는 방법으로 PSPI(Photo-sensitive polyimide)를 이용해 패터닝 (Patterning)을 실시하여 보호막을 형성하였다. 스핀 코팅된 폴리이미드는 $350^{\circ} \mathrm{C}$ 에서 큐어링(curing)을 실시하여 기판에 폴리이미드가 완전히 접착되도록 하였다. 그림 5는 위의 과정 을 통해 제작된 $16 \times 16 \mathrm{FPA} \mathrm{APD}$ 이다.

시간정보에 해당하는 광 신호를 디지털신호로 변환하기 위 해서는 고속의 회로 설계 및 $\mathrm{CMOS}$ 공정이 필요하며, 이를 위해 고속동작을 위한 PLL 및 DLL를 삽입하여 고속 동작을 
도모하고 고속 동작이 가능한 $0.18 \mathrm{um} \mathrm{CMOS}$ 공정을 이용 하여 ROIC를 제작하였다. 그림 6(a)는 제작된 ROIC이며, 전 체 칩 사이즈는 $5.2 \mathrm{~mm} \times 5.2 \mathrm{~mm}$ 이다. 제작된 $\mathrm{ROIC}$ 의 거리

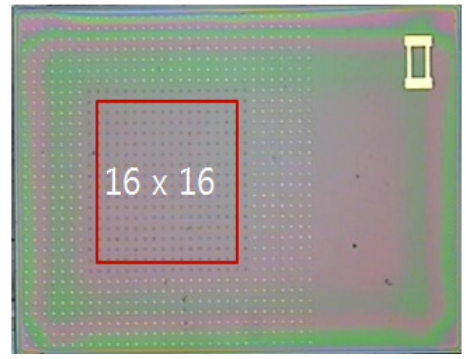

FIG. 5. Photography of fabricated $16 \times 16$ FPA APD chip.

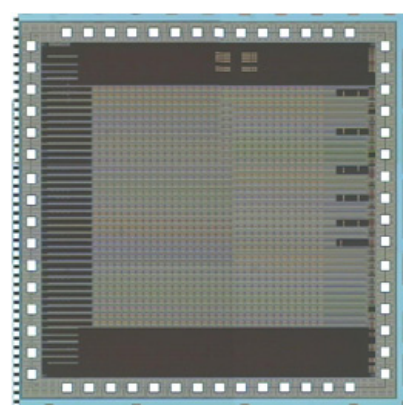

(a)

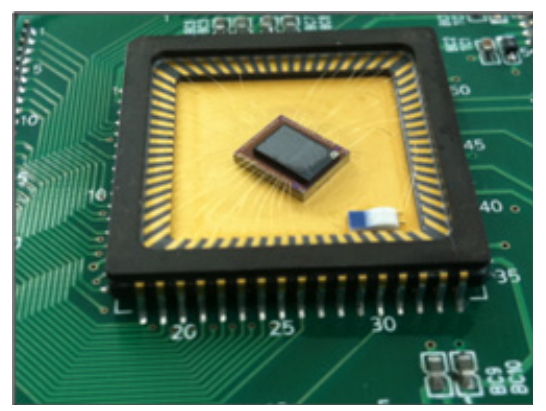

(b)

FIG. 6. Photography of fabricated ROIC chip and InGaAs FPA chip-on-submount. (a) Photography of ROIC (b) InGaAs FPA chip-on-submount.

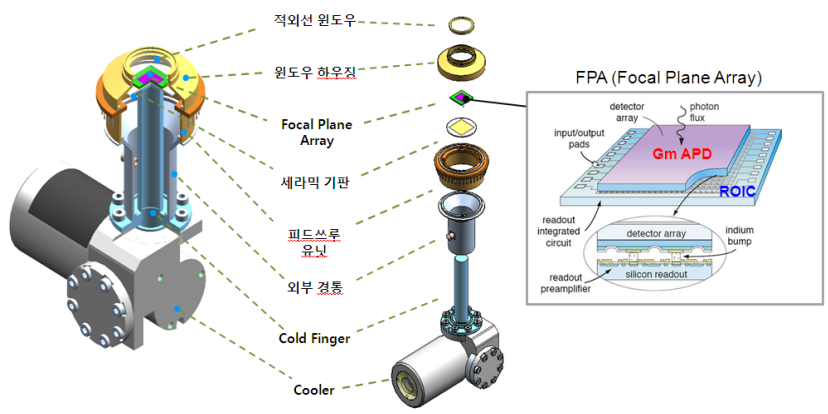

FIG. 7. Photography of fabricated LADAR optical receiver with Geiger-Mode $16 \times 16$ FPA APD.
정확도 측정결과로써 $1 \mathrm{~km}$ 거리 구간에 대해서 구간별로 $15 \mathrm{~cm}$ 이하의 거리정확도 결과를 얻었다.

광수신기에 입사되는 광자(Photon)의 흡수율을 높이기 위 해 Back-side Thinning, 배열소자의 표면 반사를 최소화하기 위한 AR Coating, 그리고 활성 영역(Active area) 이외의 영 역에 입사된 Carrier의 확산에 의해 발생하는 Primary pulsing 영향을 제거하기 위해 패터닝(Patterning)을 적용한 APD 배 열소자와 $\mathrm{ROIC}$ 를 하이브리드 범프 공정을 통해서 전기적으 로 결합하여 16×16 FPA를 제작하였다.(그림 6(b) 참조) 그림 7 은 제작된 $16 \times 16 \mathrm{LADAR}$ 광수신기며, $\mathrm{LADAR}$ 광수신기의 동작온도는 냉각기에 의해 $240 \mathrm{~K}$ 으로 유지된다.

\section{IV. 특성 및 논의}

그림 8 에 제작된 $16 \times 16 \mathrm{FPA}$ 소자의 전류-전압 특성을 광 신호가 입사했을 때(Photocurrent)와 광신호가 없을 때(Dark current)로 나타내었다. 제작된 16×16 FPA 소자는 63-67 V 분포의 항복전압을 나타내었으며, 그림 8 로부터 배열소자의 항복전압은 $72 \mathrm{~V}$ 이고, 항복전압의 $90 \%$ 에 해당하는 인가전 압에서 정의되는 암 전류(Dark Current)는 상온 $300 \mathrm{~K}$ 에서 수십 $\mathrm{pA}$ 를 보였으며, 항복전압 및 전류 균일도는 $0.6 \%$ 를 보 였다. 본 연구에서 제작한 3 차원 영상 LADAR 광수신기는 검출 민감도가 매우 높고, 신호처리 과정이 단순하여 단일 광자까지 검출 가능한 디지털모드(Geiger Mode)를 사용하였 다. 디지털모드(Geiger Mode)는 증폭 이득이 커 단일 광자를 검출할 수 있지만 광수신기의 암 전류(Dark Current)에 의한 $\mathrm{DCR}$ 의 크기는 3 차원 영상 획득에 가장 큰 변수라고 할 수 있다. 따라서 DCR을 최소화 할 수 있는 배열소자 설계, 제 작이 실행되어야 한다. 제작된 3차원 영상 $\mathrm{LADAR}$ 광수신기 의 $240 \mathrm{~K}$ 동작 온도에서 $\mathrm{DCR}$ 은 $140 \mathrm{kHz}$ 의 특성을 보였다. 또한, 단일 광자 검출 확률을 나타내는 $\mathrm{PDE}$ 는 $28 \%$ 이다. (그림 9 참조)

그림 10 은 제작된 LADAR 광수신기의 자체 시험을 위해,

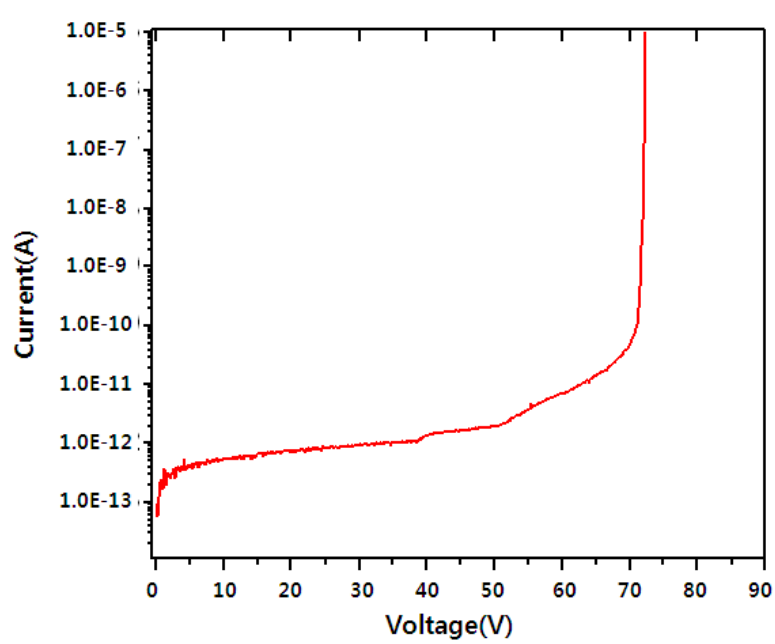

FIG. 8. Measured results of dark current for $16 \times 16$ FPA APD. 

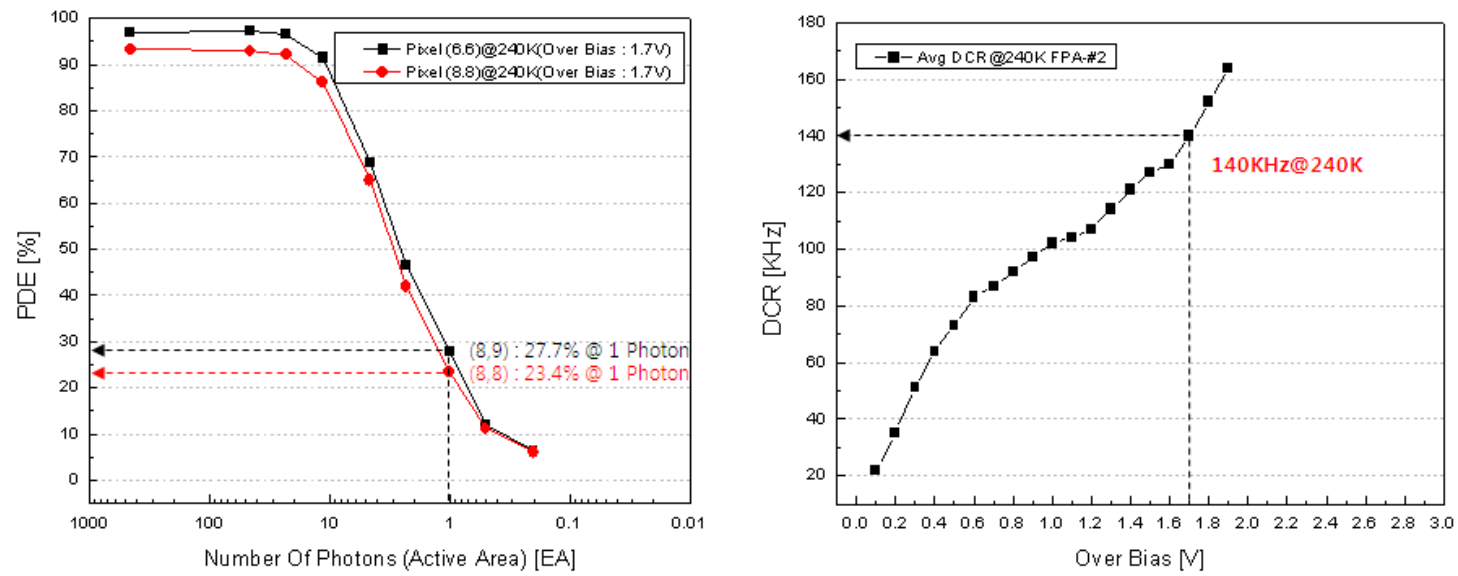

FIG. 9. Measured results of PDE and DCR for $16 \times 16$ FPA APD.
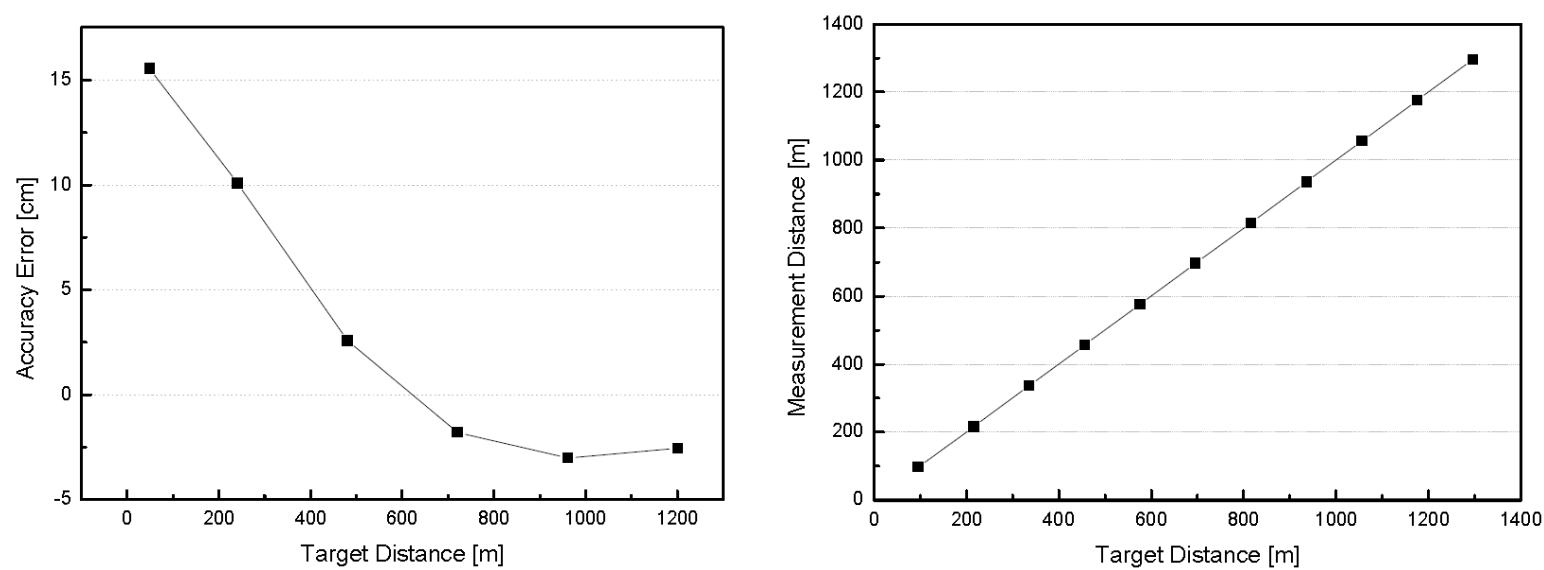

FIG. 10. Distance linearity measurement result and analysis of distance accuracy for $16 \times 16$ FPA.

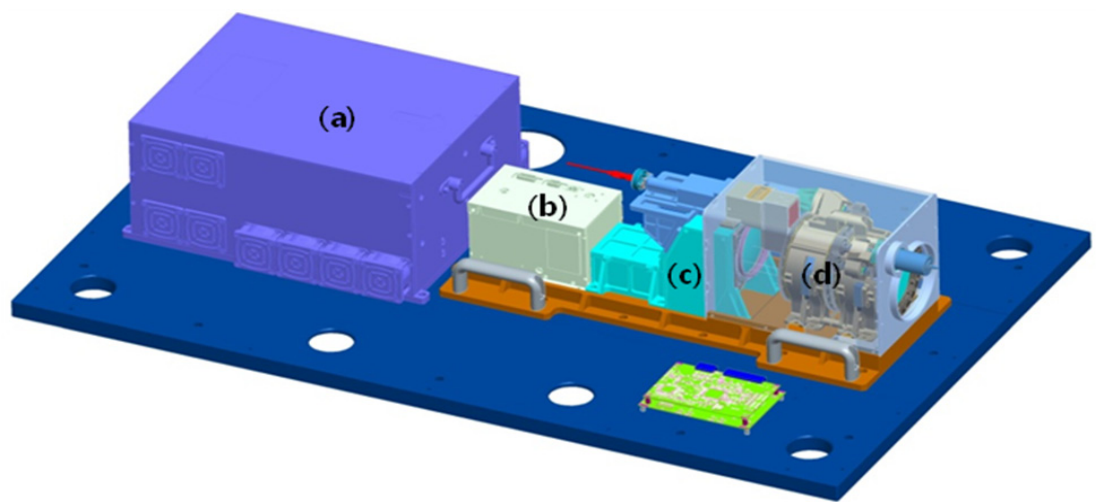

FIG. 11. Photography of fabricated LADAR system. (a) Laser module (b) $16 \times 16$ FPA optical receiver module (c) Active optical system (d) Scanner module.

레이저 광을 시간지연 시켜 광수신기에 입사시킨 다음 시간 지연에 해당하는 거리를 광수신기로 특성을 평가하였으며, 거리 선형성과 거리정확도를 시험한 결과이다. 제작된 광수 신기는 $80 \mathrm{~cm} \sim 90 \mathrm{~cm}$ 의 거리 정확도를 나타내고 있음을 확 인하였다. 이는 ROIC의 TDC의 분해능에 못 미치는 결과로 써 측정 시스템의 오류로 판단되며, 측정 시스템의 구성을
최적화하여 개선할 수 있을 것으로 판단된다.

그림 11은 제작된 LADAR 시스템으로써 레이저 모듈, 송 수광 광학계, 스캐너 모듈, $16 \times 16 \mathrm{FPA}$ 광수신기로 이루어져 있으며, 획득된 거리 정보를 로직 모듈에서 3차원 공간영상 으로 전시한다. LADAR 시스템은 $25 \mathrm{kHz}$ 펄스 레이저(Pulsed laser)를 송광 광학계를 통해 조사하게 되고, 조사되는 레이 


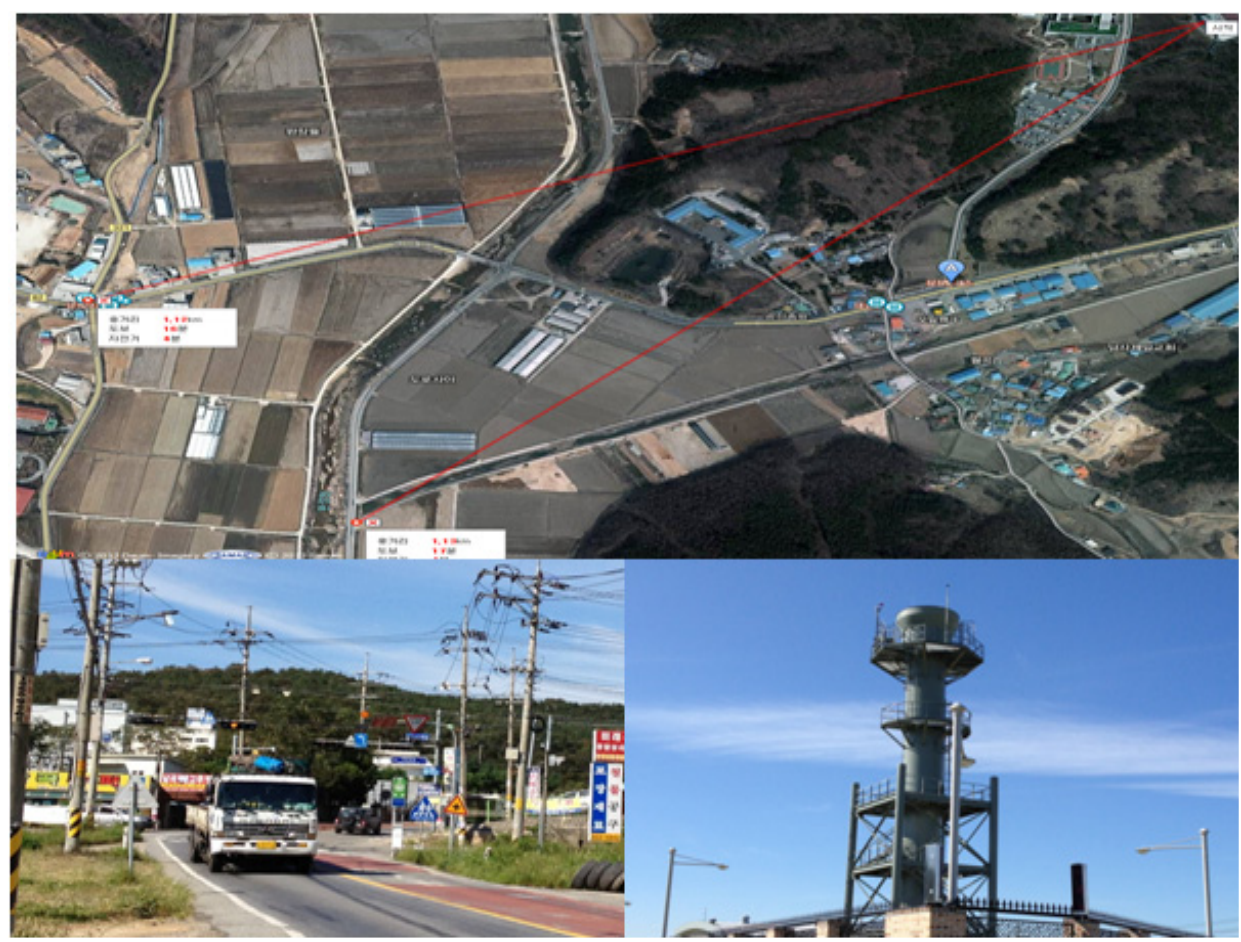

(a)

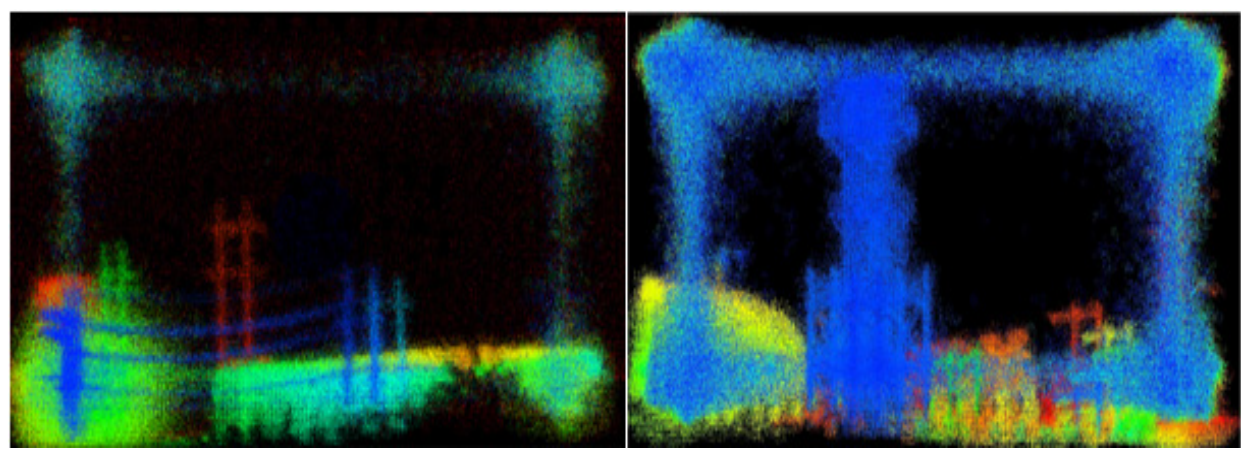

(b)

FIG. 12. The LADAR system showed that signals from distance up to $1 \mathrm{~km}$ apart could be detected, (a) Actual photography at $1.1 \mathrm{~km}$ (b) 3-Dimensional images obtained from LADAR system.

저 시작 시점을 별도의 광수신기에서 수신하여 스캐너 모듈 과 로직 모듈로 보내게 된다. 조사된 펄스 레이저(Pulsed laser)는 표적에서 반사되어 수광 광학계를 통해 $16 \times 16 \mathrm{FPA}$ 광수신기에서 수신하게 된다. 수신되는 펄스 레이저(Pulsed laser)는 회전 거울을 이용하여 광원을 2 차원으로 주사하는 방식으로 3 차원 공간영상을 전시하기 위해 시간 정보를 거 리 정보로 변환하여 로직 모듈로 전송한다. 로직 모듈은 수 신된 거리 정보를 3 차원 공간영상으로 전시하게 된다. 본 연 구에서 제작된 LADAR 시스템은 디지털모드(Geiger Mode) 의 $16 \times 16 \mathrm{FPA} \mathrm{APD}$ 광수신기에서 시야각 $2.3^{\circ} \times 1.3^{\circ}$ 영역의 거리 정보를 받아 3 차원 공간영상으로 전시한다. 그림 12 은 LADAR 시스템에서 3 차원 영상 획득 시나리오를 통해 획득 된 실제 영상이다. 측정 거리는 약 $1.1 \mathrm{~km}$ 지역이며, 철탑과 일반적인 거리의 3 차원 공간영상을 획득하였다. 3 차원 공간
영상 획득을 통해 실제 전신주의 전선까지 공간영상으로 획 득됨을 확인하였다.

\section{V. 결 론}

본 연구에서는 3 차원 영상 LADAR를 구현하기 위한 InGaAs$\mathrm{InP}$ 계 화합물 반도체를 이용하여 플래너(Planar)구조 형태로 $16 \times 16 \mathrm{FPA} \mathrm{APD}$ 를 이용한 광수신기 모듈을 제작하고, 그 특 성을 측정하였다. 플래너(Planar)구조의 장점인 P-N접합 영 역을 제어하기 위해 $\mathrm{Zn}$ 확산을 Closed Ampoule 방법을 채택 하여 접합을 형성하였으며, 전자사태(Avalanche)가 발생하는 영역 즉 증폭층 영역을 $\mathrm{Zn}$ 확산 법으로 $0.1 \mathrm{um}$ 단위로 정밀 하게 제어하였다. 제작된 배열소자는 증폭층 $1 \mathrm{um}$, 폴리이미 드(Polyimide)를 보호박막으로 제작함으로써 암전류 값은 $55 \mathrm{pA}$ 
이하의 결과를 얻었고, 증폭층 설계에 있어서 증폭층의 폭을 $1 \mathrm{um}$ 이상으로 설계하고 침식 전압(Punch-through voltage)와 항 복 전압을 가까이 설계할수록 더 낮은 암 전류 값을 가지는 소자를 제작 할 수 있었다. 접합 구조는 1차 확산과 2차 확 산 간의 간격 D1(2 um)과, 주 접합면과 Floating Guardring 사이의 간격 $\mathrm{D} 2(7 \mathrm{um})$ 로 제작하여 최적의 소자 동작 특성을 가질 것으로 판단된다. 제작된 배열소자의 디지털모드 (Geiger-mode) 구동 특성을 파악하기 위해 시험 장치를 설계 및 구성하여 시험하였고, 배열소자 측정 시 $240 \mathrm{~K}$ 에서 DCR 이 $140 \mathrm{kHz}$ 특성을 보였다. 또한, 단일 광자 검출 확률을 나 타내는 PDE는 $28 \%$ 의 특성을 보였다.

\section{References}

1. S. Verghese, K. A. McIntosh, Z. L. Liau, C. Sataline, J. D. Shelton, J. P. Donnelly, J. E. Funk, R. D. Younger, L. J. Mahoney, G. M. Smith, J. M. Mahan, D. C. Chapman, D. C. Oakley, and M. Brattain, "Arrays of $128 \times 32$ Inp-based Geiger-mode avalanche photodiodes," Proc. SPIE $\mathbf{7 3 2 0}$, 7320M-1-8 (2009).

2. http://en.wikipedia.org/wiki/Time-of-flight_camera\#cite_note-16.

3. J. P. Donnelly, E. K. Duerr, K. A. McIntosh, E. A. Dauler,
D. C. Oakley, S. H. Groves, C. J. Vineis, L. J. Mahoney, K. M. Molvar, P. I. Hopman, K. E. Jensen, G. M. Smith, S. Verghese, and D. C. Shaver, "Design considerations for 1.06 um InGaAsP-InP geier-mode avalanche photodiodes," IEEE J. Quantum Electron. 42, 797-809 (2006).

4. J. Asbrock, S. Bailey, D. Baley, J. Boisvert, G. Chapman, G. Crawford, T. de Lyon, B. Drafahl, J. Edwards, E. Herrin, C. Hoyt, M. Jack, R. Kvaas, K. Liu, W. MckKeag, R. Rajavel, V. Randall, S. Rengarajan, and J. Riker, "Ultra-high sensitivity APD based 3D LADAR sensors," Proc. SPIE 6940, 69400 (2008).

5. K. S. Hyun and C. Y. Park, "Breakdown characteristics in $\mathrm{InP} / \mathrm{InGaAs}$ avalanche photodiode with p-i-n multiplication layer structure," J. Appl. Phys. 81, 974-984 (1997).

6. D. Mosconi, D. Stoppa, M. Malfatti, M. Perenzoni, M. Scandiuzzo, and L. Gonzo, "A CMOS sensor based on single photon avalanche diode for fluorescence lifetime measurements," in Proc. Inst. \& Meas. Technology Conference, IMTC 2006 (Sorrento, April 2006), pp. 416-419.

7. H. Ando, "Low-temperature $\mathrm{Zn}$ and Cd-diffusion profiles in InP and formation of guard ring in InP avalanche photodiodes," IEEE Transactions on Electron Devices 29, 1408-1413 (1982). 